\title{
Comparison of TNF- $\alpha$ and TGF- $\beta$ Expression in Breast Cancer Tissues-with and without Axillary Lymph Node Metastasis
}

\author{
Ayu Tyasmara, Willy Sandhika \\ Department of Anatomical Pathology, Universitas Airlangga Surabaya
}

\section{ARTICLE INFO}

Article history

Received 08 June 17

Received in revised form 29 September 17

Accepted 09 February 18

\section{Keywords:}

Breast carcinoma, lymph nodes

metastasis, TNF- $\alpha$, TGF- $\beta$

Kata Kunci:

Karsinoma payudara, metastasis

kelenjar getah bening, TNF- $\alpha$, TGF- $\beta$

\begin{abstract}
Background: Breast carcinoma dynamics can be seen from the inflammatory mediator produced and some of expressed cytokine mediators mostly found in breast cancer tissues are TNF- $\alpha$ and TGF- $\beta$. This research analyzed TNF- $\alpha$ and TGF- $\beta$ influence in axillary lymph nodes metastasis to prove the role of cytokines in breast cancer dynamics and to be taken as prognosis.
\end{abstract}

Methods: This research used paraffin block of breast carcinoma in various stages of axillary lymph nodes metastasis and TNF- $\alpha$ and TGF- $\beta$ antibody to observe the expressions.

Result: There were significant differences in TNF- $\alpha$ expressions improvement with $p<0.05$ in lymph nodes metastasis N1 (13.18\%) and TNF- $\alpha$ expressions reduction in lymph nodes metastasis N2 (52.27\%) and N3 (27.27\%) compared with lymph nodes without metastasis (52.73\%). There were no significant differences in TGF- $\beta$ expressions of all $N$ groups.

Conclusion: The result stated that TNF- $\alpha$ cytokines can be used as biomarker independently predicting breast carcinoma prognosis and progressivity.

\section{ABSTRAK}

Latar Belakang: Dinamika karsinoma payudara tercermin dari mediator inflamasi yang dihasilkannya dan salah satu mediator sitokin yang terekspresi banyak pada jaringan tumor payudara adalah TNF- $\alpha$ and TGF- $\beta$. Kami menganalisis pengaruh TNF- $\alpha$ dan TGF- $\beta$ pada metastasis kelenjar getah bening aksila untuk membuktikan peran sitokin dalam dinamika kanker payudara dan untuk dimanfaatkan sebagai alat prognosis.

Metode: Penelitian ini menggunakan blok parafin karsinoma payudara pada berbagai stadium metastasis kelenjar getah bening aksila dan menggunakan antibodi TNF- $\alpha$ dan TGF- $\beta$ untuk mendeteksi ekspresinya.

Hasil: Hasil penelitian ini didapatkan perbedaan peningkatan ekspresi TNF- $\alpha$ yang signifikan dengan $p<0,05$ pada metastasis kelenjar getah bening $N 1(73,18 \%)$ dan penurunan ekspresi TNF- $\alpha$ pada metastasis kelenjar N2 $(52,27 \%)$ dan N3 $(27,27 \%)$ dibandingkan dengan tanpa metastasis (52,73\%). Tidak ada perbedaan signifika $n$ pada ekspresi TGF- $\beta$ antar semua kelompok $\mathrm{N}$.

Kesimpulan: Hasil ini menyatakan sitokin TNF- $\alpha$ dapat dipakai sebagai biomarker untuk memprediksi progresifitas dan prognosis karsinoma payudara secara independen.

\section{INTRODUCTION}

Breast carcinoma has been an issue among our community that draws huge attention from health industries and researchers in Indonesia. It is because the carcinoma has a high prevalence which reaches 0.5 of 1,000 women, according to Basic Health Research year 2013. ${ }^{1}$ Indonesia mortality rate gives $17 \%$ of 
carcinoma patients' mortality in the whole Asia Pacific (8 in every 100,000$)(2)$.

Breast carcinoma therapy has been developed since the last three decades, nonetheless the survival rate of breast carcinoma cases with metastasis is still poor, ${ }^{3}$ this becomes crucial to get more attention. One of the biggest problems in breast carcinoma therapy is the cost that burdens both the government and patients. The use of predictive biomakers as targeted therapy response shall be able to increase therapy effectiveness therefore decrease the cost. However, application and further development in identifying the predictive biomarkers is so poor in Indonesia. At the other hand, targeted therapy failed because of tumor resistance and breast carcinoma staging system failure in representing the patient's clinical outcome become the main focus in assuming side factors in breast carcinoma. Another variable that can be involved is immune system inflammatory mediator, namely cytokine that plays role as a natural immunity for cancer patient also as cancer progressivity. ${ }^{4}$ Protumoral inflammatory cytokine in this cancer is also supported by another clinical research that found the correlation between high inflammatory cytokine and poor patients' prognosis. ${ }^{4}$ The importance of cytokine as antitumoral and pro-tumoral shows that the immunology parameter is significant and beneficial in examining cancer patients' prognosis.

TNF- $\alpha$ and TGF- $\beta$ are two cytokines highly expressed in breast carcinoma tissues and significantly correlated with tumor mass, tumor stages, and lymph nodes metastasis. ${ }^{5,6}$ TNF- $\alpha$ in immune system takes part as antitumoral because it stimulates apoptosis and cell death, but in a long time it contributes in tumor cell development to become more progressive since it will be able to activate NF-k $\beta .^{7,8} \mathrm{NF}-\mathrm{k} \beta$ is also the most observed cytokine in breast carcinoma. TGF- $\beta$ is a pro-apoptosis and anti-proliferative cytokine in immune system to fight cell cancer, moreover TGF- $\beta$ is a cytokine that able to stimulate collagen production by activating Tissue Inhibitor Metalloproteinase (TIMP). The activation of TIMP also retains MMP work therefore becoming tumor cell barricade to invade the surrounding tissues. ${ }^{9}$ Axillary lymph nodes influence is the most important prognostic factor having direct correlation with further metastasis risk and recurrency. ${ }^{10}$

TNF- $\alpha$ and TGF- $\beta$ different expressions showed in various metastasis stages of axillary lymph nodes using immunohistochemical analysis are expected to clarify the inflammatory mediator influence and roles toward patient's axillary lymph nodes status.

\section{MATERIAL AND METHOD}

This research applies cross-sectional study taking data and paraffin block randomly from Anatomical Pathology Laboratory of $\mathrm{dr}$. Soetomo Surabaya public hospital archive, during the period of 1 January 2015 until 31 December 2016, 44 paraffin blocks of Invasive Carcinoma of No Special Type breast cancer with different grades and tumor mass (T), divided into 11 samples of each stadium of axillary lymph nodes (LN) without metastasis ((N0), with metastasis 1-3 axillary LN (N1), metastasis 4-9 axillary LN (N2), and metastasis $\geq 10$ axillary LN (N3).

Within the paraffin blocks, immunohistochemical analysis was conducted using mice anti monoclonal antibodies to human TNF- $\alpha$ expression (PeproTech) with 1:200 dilution and mice anti monoclonal antibody raised against recombinant TGF $\beta 1$ of human origin (Santa Cruz) with 1:100 dilution. TNF- $\alpha$ and TGF- $\beta$ examination were performed by comparing the number of positive cells to the whole tumor cells and resulted in percentage (0$100 \%)$. The collected data was then examined with SPSS 17.0 using Kruskal-Wallis and Mann-Whitney statistic test to find out different TNF- $\alpha$ and TGF- $\beta$ expression in various metastasis stages of axillary lymph nodes. The institutional Review Board at Medical Faculty of Airlangga University and Soetomo General Hospital approved the study and all patients provided informed consent to participate No. 633/Panke.KKE/XI/2016.

\section{RESULT \\ Characteristic of the Sample}

The research found that the mean of patients' age was 54.32 years old \pm 10.64 years. The youngest patient was 28 years old and the oldest was 83 years old. In this research, the ages were grouped in 5 different groups with 10 years range to make the observation easier. It can be seen that the highest frequency was of age 45-55 with 20 cases $(40 \%)$

Table 1. Characteristic Data

\begin{tabular}{lcc}
\hline Patient Characteristic & Number & Percentage \\
\hline Age (years) & 20 & $40,0(45-55)$ \\
Tumor size & 23 & $26,0(\mathrm{~T} 2)$ \\
Grading & 30 & 60,0 \\
\hline
\end{tabular}


All tumors in this research were Invasive Carcinoma of NST (Infiltrating Ductal Carcinoma/IDC) with different grades. Resulted in this research that 30 cases $(60 \%)$ were Invasive Carcinoma of NST (Infiltrating Ductal Carcinoma/IDC) grade 3, 34\% were Invasive Carcinoma of NST (Infiltrating Ductal Carcinoma/IDC) grade 2, and $6 \%$ were Invasive Carcinoma of NST (Infiltrating Ductal Carcinoma/IDC) grade 1 .

Stage $T$ characteristic used as sample in this research consisted of T2 stage as the highest number of cases with 23 cases (26\%), followed by T4 stage as many as 10 cases (20\%), 9 cases of T3 stage (18\%), and T1 stage as many as 8 cases (16\%).

Average TNF- $\alpha$ expressions of lymph nodes without metastasis (NO) group was $52.73 \%$. Sample group with metastasis N1 had the mean percentage of $73.18 \%$. Sample group with metastasis N2 had the mean percentage of $52.27 \%$, and sample group with metastasis N3 had the mean percentage of $27.27 \%$. Statistical analysis conducted in Kruskal Wallis and MannWhitney in intra-sample group resulted significant difference among all $N(p<0.05)$ axillary lymph nodes metastasis groups.

Table 2. Distribution of TNF- $\alpha \alpha$ expressions in axillary lymph nodes stages

\begin{tabular}{|c|c|c|c|c|c|c|}
\hline \multirow{2}{*}{ Metastasis } & \multirow{2}{*}{$\mathbf{N}$} & \multicolumn{4}{|c|}{ TNF- $\alpha$} & \multirow{2}{*}{$p$} \\
\hline & & $\bar{x}$ & SD & Min & Max & \\
\hline NO & 11 & 52.73 & 16.64 & 20 & 85 & \multirow{4}{*}{$0.000^{*}$} \\
\hline N1 & 11 & 73.18 & 11.24 & 50 & 90 & \\
\hline N2 & 11 & 52.27 & 21.02 & 30 & 90 & \\
\hline N3 & 11 & 27.27 & 20.90 & 5 & 70 & \\
\hline
\end{tabular}

Picture 1. TNF- $\alpha$ expressions in axillary lymph nodes metastasis stages

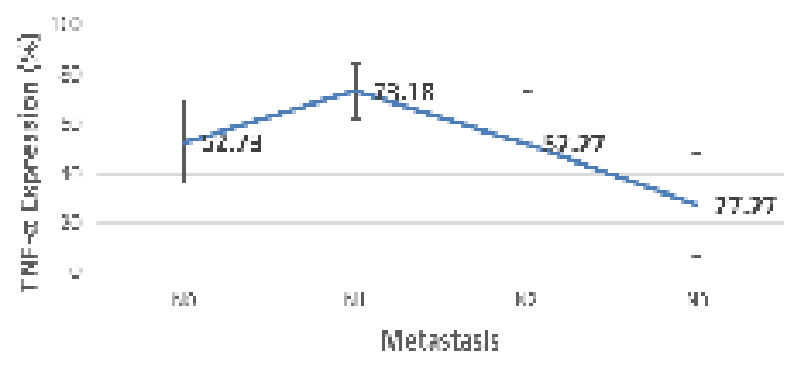

Picture 2. (A) Tumor with $90 \% \mathrm{TNF}-\alpha$ positive; (B) Tumor with $25 \%$ TNFa positive
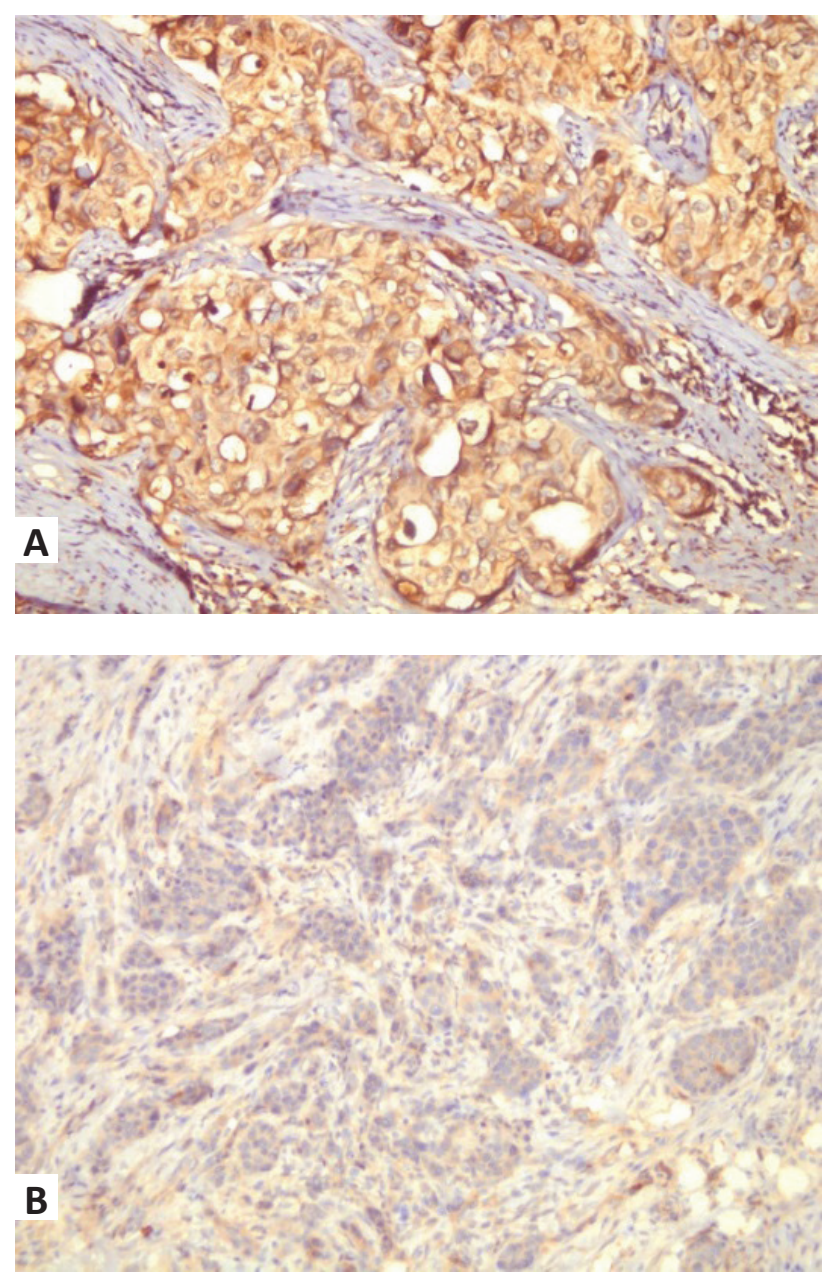

TGF- $\beta$ antibody exposure statistical analysis result after Kruskal Willis statistical and Mann Whitney test showed that there were no significant differences between the number of cell that expressed TGF- $\beta$ among all groups of axillary lymph nodes metastasis $N(p>0.05)$. The result of TGF- $\beta$ expression in this research showed non-uniformity in various sample groups.

Table 3. Distribution of TGF- $\beta$ expressions in various axillary lymph nodes stages

\begin{tabular}{|c|c|c|c|c|c|c|c|}
\hline \multirow{2}{*}{ Metastasis } & \multirow{2}{*}{$\mathbf{N}$} & \multicolumn{5}{|c|}{ TGF- $\beta$} & \multirow{2}{*}{$\mathbf{P}$} \\
\hline & & $\bar{x}$ & SD & Median & Min & Max & \\
\hline NO & 11 & 30.45 & 22.07 & 20 & 10 & 70 & \multirow{4}{*}{0.636} \\
\hline $\mathrm{N} 1$ & 11 & 41.82 & 29.52 & 40 & 5 & 70 & \\
\hline N2 & 11 & 28.64 & 23.14 & 20 & 5 & 70 & \\
\hline N3 & 11 & 45.27 & 36.11 & 50 & 3 & 95 & \\
\hline
\end{tabular}


Picture 3. (A) Tumor with $25 \%$ TGF- $\beta$ positive; (B) Tumor with $95 \%$ TGF- $\beta$ positive
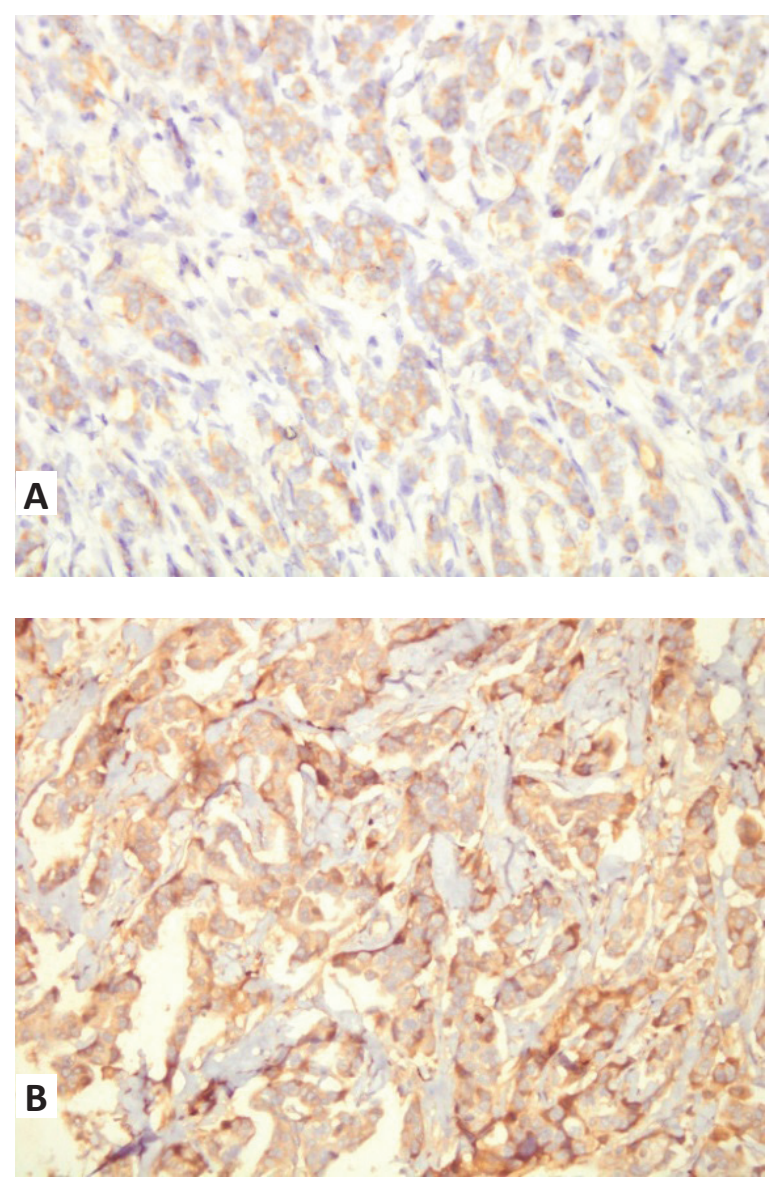

Picture 4. TGF- $\beta$ expressions in various axillary lymph nodes stages.

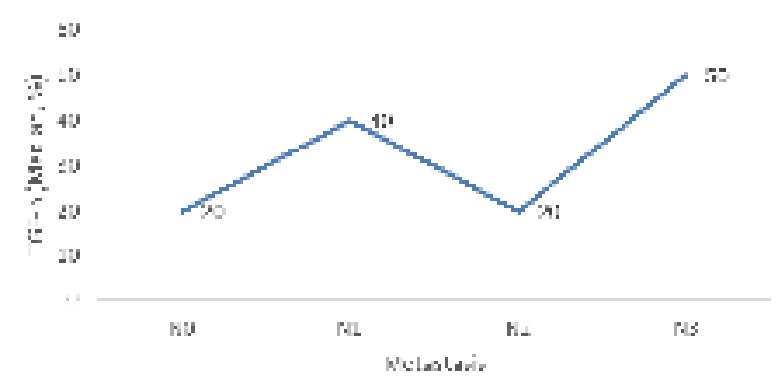

\section{DISCUSSION}

Statistical analysis and Kruskal-Wallis test among sample groups resulted significant increase of mean $(p<$ 0.05 ) between sample group NO and N1, with TNF- $\alpha$ expressions' mean higher in N1 than N0 (N1 > N0). This result was in accordance to literatures stating that in its early stage of cancer, TNF- $\alpha$ will increase in line with the increase of innate immune response, and that this condition will happen during initiation stages. The development is related to innate immune response whenever strange cell is occurred, in this case, cancer. ${ }^{10}$ TNF- $\alpha$ will bind with TNFR1 $\alpha$ (p55), the binding will activate cell signal to die by inducing apoptosis through stages of caspase especially TRADD, RIP, FADD caspase and caspase-8.6 Moreover, anti tumoral TNF- $\alpha$ function will cause cancer cell lysis directly through hydroxyl radical and lysosomal enzyme. ${ }^{7}$ Other literatures state that TNF- $\alpha$ expression in tumor (tumor islets) functioned as patients' cytotoxic response to fight tumor progressiveness, TNF- $\alpha$ expression density of the tumor is an independent factor in patients' survival prediction. ${ }^{8}$

Chronic cancer condition generates suppressive effects towards TNF- $\alpha$ that there will be TNF- $\alpha$ deficiency and TNF- $\alpha$ blockade. This caused TNF- $\alpha$ expression to be lower. ${ }^{11}$ The immune system of breast carcinoma patients with higher lymph nodes metastasis stage (N2 and N3) will not be able to keep up with the increasing tumor progressiveness and proliferation. It is because a condition with full inflammatory mediator occurred in high metastasis stage for a long time will make tumor cell in anegery state, a condition when body defense reaction towards strange objects lessen and immune system tolerance occurred. This condition is caused by two things, namely the merging of regulatory immune cells with immune suppressor cells and the pilled immunosuppresant cytokines in high concentration, for example IL10 and TGF- $\beta .^{7}$ On a higher stage TNF- $\alpha$ apoptosis will also be partially constrained through caspase- 8 constraint by cellular FLICE. The FLICE protein (c-FLIP) will compete with caspase in binding FADD that it will block the mitochondria through family member with anti-apoptosys Bcl2. TNF- $\alpha$ apoptosis through Reactive Oxygen Species (ROS) will also be damaged because of genetic changes of breast carcinoma, therefore in higher stage the cancer cell will have the ability to avoid death cell lane induced by TNF- $\alpha$. TNF- $\alpha$, their roles as an anti-tumoral will weaken and TNF- $\alpha$ apoptosis will turn into anti-apoptosis and support further malignant proliferation process, through NF-k $\beta$ that restrains JNK apoptosis activation and will support cell poliferation. ${ }^{12}$ Kruskal Willis statistical analysis resulted that there were no significant differences in the number of cells that expressed TGF- $\beta$ among all axillary lymph nodes metastasis groups $N(p>0.05)$. TGF- $\beta$ expressions resulted in this research also showed nonuniformity in various sample groups, nonetheless compared with axillary lymph nodes without metastasis (N0) sample group, TGF- $\beta$ expression in sample group N1 and N3 increased, meanwhile it was decreased in N2. This result was in accordance with the previous research 
statement that TGF- $\beta$ is an independent prognostic factor toward breast carcinoma lymph nodes metastasis and a high expression of TGF- $\beta$ was found in breast carcinoma lymph nodes without metastasis group (NO) with higher recurrence risk in sample groups with increasing TGF- $\beta$ expression. ${ }^{13}$ The above chart of TGF- $\beta$ expression shows non-linear graphic that indicates the high dynamic changes of TGF- $\beta$ expression.

\section{CONCLUSION}

This research shows that there are significant differences of TNF- $\alpha$ expressions in different axillary lymph nodes stages, where TNF- $\alpha$ increaseds in lymph nodes metastasis early stages (N1) and TNF- $\alpha$ decreaseds in lymph nodes metastasis higher stages (N2 and N3) also, there were no significant differences of TGF- $\beta$ expressions among all lymph nodes metastasis stages. It shows that TNF- $\alpha$ inflammatory mediator took role in breast carcinoma that involveds axillary lymph nodes metastasis. Meanwhile, significant differences were not found in TGF- $\beta$ expressions among all groups of axillary lymph nodes metastasis.

\section{ACKNOWLEDGEMENTS}

The authors thanks Willy Sandhika, MD from the Departments of Anatomical Pathology, for sharing the TNF- $\alpha$ positive control of inflammation, and Hari Basuki, MD from Departments of Community Medicine for sharing statistical aspect of this study. The author also acknowledges the member of Anatomical Pathology Airlangga University Laboratory for their assistance. The authors have no conflict of interest to disclose.

\section{REFERENCES}

1. Departemen Kesehatan Republik Indonesia. Riset Kesehatan Dasar. Badan Penelitian dan pengembangan Kesehatan Kementrian Kesehatan RI. Pusat Data dan Informasi 2015; 1-8.

2. Youlden Danny R, Cramb Susanna M, Cheng Har Yip, Baade D Peter. Incidence and Mortality of Female Breast Cancer in The Asia Pasific Region. Cancer Bio Med 2014; 11: 101-115.
3. Leo Angelo Di, Curigliano Giuseppe, Dieras Veronique dkk. Review New approaches for improving outcomes in breast cancer in Europe. The Breast 2015; 24: 321-330.

4. Mantovani Alberto, Schioppa Tiziana, Porta Chiara, Allavena Paola, Sica Antonial. Role of tumor - associated macrophages in tumor progression and invasion. Cancer metastasis Rev 2006; 25: 315-322.

5. Xian-Long Zhou, Wei Fan, Gui Yang, dan Ming-Xia Yu. The Clinical Significance of PR, ER, NF-k $\beta$, and TNF- $\alpha$ in Breast Cancer. Research article 2014; 101: 543-55.

6. Kleuser, B., Malek, D., Gust, R., et al. 17- $\beta$-estradiol inhibits transforming growth factor- $\beta$ signaling and function in breast cancer cells via activation of extracellular signalregulated kinase through the $\mathrm{G}$ protein-coupled receptor 30. Mol Pharmacol 2008; 74(6):1533-43.

7. Ming-Ju Tsai, Wei-An Chang, Ming-Shyan Huang,dan Po-Lin Kuo. Review Article Tumor Microenvironment: A New Treatment Target for Cancer. ISRN Biochem 2014; 1-8.

8. Miles, D.W., Happerfield, L.C., Naylor, M.S., Bobrow, L.G., Rubens, R.D., Balkwill, F.R.. Expression of tumor necrosis factor (TNF- $\alpha$ ) and its receptors in benign and malignant breast tissue. Int J Cancer 1994; 56:777-782.

9. Stuelten Christinap Byfield Stacey DaCosta, Arany Praveen R., Karpova Tatiana S., .Stetler-Stevenson William G dan Roberts Anita B. Breast cancer cells induce stromal fibroblasts to express MMP-9 via secretion of TNF- $\alpha$ and TGF- $\beta$. Journal of Cell Science 2005; 118: 2143-2153.

10. Stankov A., Bargallo-Rocha J.E., Silvio Namendys-Silva A., Ramirez M.T., Stankova-Ninova K., dan Meneses-Garcia A. Prognostic Factors and Recurrence in Breast Cancer: Experience at the National Cancer Institute of Mexico. Onc 2012; Vol.2012: 1-8

11. Treede Irina, Braun Annika, Jeliaskova Petia et al,. TNF- $\alpha$ Induced up Regulation of Pro Cytokines Is Reduced by Phosphatidylcholine in Intestinal Epithelial Cells. BMC Gastroenterology 2009; 9,53.

12. Kim HJ, Litzenburger BC, Cui $X$ et al. Constitutively active type I insulin-like growth factor receptor causes transformation and xenograft growth of immortalized mammary epithelial cells and is accompanied by an epithelial-to-mesenchymal transition mediated by NFkappaB and snail. Mol Cell Biol 2007; 27: 3165-3175.

13. Desruisseau S, Palmari J, Giusti C, Romain S, Martin P-M dan Berthois $Y$. Determination of TGF- $\beta$ protein level in human primary breast cancers and its relationship with survival. British Journal of Cancer 2006; 94: 239. 